UNIVERSITÉ DE LAUSANNE - FACULTÉ DE BIOLOGIE ET DE MÉDECINE Institut Universitaire de Médecine Sociale et Préventive

\title{
Meta-analysis: Subclinical Thyroid Dysfunction and the Risk for Coronary Heart Disease and Mortality
}

\section{THÈSE}

préparée sous la direction du Professeur associé Jacques Cornuz avec la collaboration du Docteur Nicolas Rodondi, Privat-Docent et Maître d'Enseignement et de Recherche,

et présentée à la Faculté de biologie et de médecine de

l'Université de Lausanne pour l'obtention du grade de

\section{DOCTEUR EN MÉDECINE}

par

Nicolas OCHS

Médecin diplômé de la Confédération Suisse

Originaire de Duillier (VD) 


\section{Rapport de synthèse}

\section{Nom du doctorant: Nicolas OCHS}

Titre de la thèse: Meta-analysis: Subclinical Thyroid Dysfunction and the Risk for Coronary Heart Disease and Mortality

Description: ce travail de thèse évalue de façon systématique les études sur l'association entre les dysfonctions thyroïdiennes infracliniques d'une part, et la maladie coronarienne et la mortalité d'autre part. Les hypothyroïdies infracliniques affectent environ $4-5 \%$ de la population adulte alors que la prévalence de l'hyperthyroïdie infraclinique est inférieure (environ 1\%). L'éventuelle association entre elles pourrait justifier un dépistage systématique des dysfonctions thyroïdiennes infracliniques. Les précédentes études sur l'association entre l'hypothyroïdie infraclinique et la maladie coronarienne ont donné des résultats conflictuels. La parution de nouveaux articles récents basés sur de grandes cohortes prospectives nous a permis d'effectuer une méta-analyse basée uniquement sur des études de cohorte prospectives, augmentant ainsi la validité des résultats.

Résultats: 10 des 12 études identifiées pour notre revue systématique sont basées sur des cohortes issues de la population générale («population-based »), regroupant en tout 14449 participants. Ces 10 études examinent toutes le risque associé à l'hypothyroïdie infraclinique (avec 2134 événements coronariens et 2822 décès), alors que 5 étudient également le risque associé à l'hyperthyroïdie infraclinique (avec 1392 événements coronariens et 1993 décès). En utilisant un modèle statistique de type random-effect model, le risque relatif [RR] lié à l'hypothyroïdie infraclinique pour la maladie coronarienne est de 1.20 (intervalle de confiance [IC] de 95\%, 0.97 à 1.49). Le risque diminue lorsque l'on regroupe uniquement les études de meilleure qualité (RR compris entre 1.02 et 1.08). Il est plus élevé parmi les participants de moins de 65 ans (RR, 1.51 [IC, 1.09 à 2.09] et 1.05 [IC, 0.90 à 1.22] pour les études dont l'âge moyen des participants est $\geq 65$ ans). Le RR de la mortalité cardiovasculaire est de 1.18 (IC, 0.98 à 1.42) et de 1.12 (IC, 0.99 à 1.26) pour la mortalité totale. En cas d'hyperthyroïdie infraclinique, les RR de la maladie coronarienne sont de 1.21 (IC, 0.88 à 1.68), de 1.19 (IC, 0.81 à 1.76 ) pour la mortalité cardiovasculaire, et de 1.12 (IC, 0.89 à 1.42) pour la mortalité totale.

Conclusions et perspectives : nos résultats montrent que les dysfonctions thyroïdiennes infracliniques (hypothyroïdie et hyperthyroïdie infracliniques) représentent un facteur de risque modifiable, bien que modéré, de la maladie coronarienne et de la mortalité. L'efficacité du traitement de ces dysfonctions thyroïdiennes infracliniques doit encore être prouvée du point de vue cardiovasculaire et de la mortalité. Il est nécessaire d'effectuer des études contrôlées contre placebo avec le risque cardiovasculaire et la mortalité comme critères d'efficacité, avant de pouvoir proposer des recommandations sur le dépistage des ces dysfonctions thyroïdiennes dans la population adulte. 


\title{
Meta-analysis: Subclinical Thyroid Dysfunction and the Risk for Coronary Heart Disease and Mortality
}

\author{
Nicolas Ochs, MD; Reto Auer, MD; Douglas C. Bauer, MD; David Nanchen, MD; Jacobijn Gussekloo, MD, MPH; Jacques Cornuz, MD, MPH; \\ and Nicolas Rodondi, MD, MAS
}

Background: Data on the association between subclinical thyroid dysfunction and coronary heart disease (CHD) and mortality are conflicting.

Purpose: To summarize prospective evidence about the relationship between subclinical thyroid dysfunction and CHD and mortality.

Data Sources: MEDLINE (1950 to January 2008) without language restrictions and reference lists of retrieved articles were searched.

Study Selection: Two reviewers screened and selected cohort studies that measured thyroid function and then followed persons prospectively to assess CHD or mortality.

Data Extraction: By using a standardized protocol and forms, 2 reviewers independently abstracted and assessed studies.

Data Synthesis: Ten of 12 identified studies involved populationbased cohorts that included 14449 participants. All 10 populationbased cohort studies examined risks associated with subclinical hypothyroidism (2134 CHD events and 2822 deaths), whereas only 5 examined risks associated with subclinical hyperthyroidism (1392 CHD events and 1993 deaths). In a random-effects model, the relative risk $(R R)$ for subclinical hypothyroidism for CHD was 1.20 $\left(95 \% \mathrm{Cl}, 0.97\right.$ to $1.49 ; P$ for heterogeneity $\left.=0.14 ; I^{2}=33.4 \%\right)$. Risk estimates were lower when higher-quality studies were pooled ( $R R, 1.02$ to 1.08 ) and were higher among participants younger than 65 years $(R R, 1.51[C l, 1.09$ to 2.09$]$ for studies with mean participant age $<65$ years and $1.05[\mathrm{Cl}, 0.90$ to 1.22$]$ for studies with mean participant age $\geq 65$ years $)$. The $R R$ was $1.18(\mathrm{Cl}, 0.98$ to 1.42$)$ for cardiovascular mortality and $1.12(\mathrm{Cl}, 0.99$ to 1.26$)$ for total mortality. For subclinical hyperthyroidism, the RR was 1.21 (Cl, 0.88 to 1.68) for CHD, $1.19(\mathrm{Cl}, 0.81$ to 1.76) for cardiovascular mortality, and $1.12(\mathrm{Cl}, 0.89$ to 1.42$)$ for total mortality $(P$ for heterogeneity $>0.50 ; 1^{2}=0 \%$ for all studies).

Limitations: Individual studies adjusted for different potential confounders, and 1 study provided only unadjusted data. Publication bias or selective reporting of outcomes could not be excluded.

Conclusion: Subclinical hypothyroidism and hyperthyroidism may be associated with a modest increased risk for CHD and mortality, with lower risk estimates when pooling higher-quality studies and larger $\mathrm{Cls}$ for subclinical hyperthyroidism.

Ann Intern Med. 2008;148:832-845.

www.annals.org

For author affiliations, see end of text.
Subclinical thyroid dysfunction refers to patients who have [TSH]) level and a normal free thyroxine $\left(\mathrm{T}_{4}\right)$ level (1). The prevalence of subclinical hypothyroidism is about $4.3 \%$ in adults $(0.7 \%$ for subclinical hyperthyroidism), and prevalence is higher in older adults and women (2-5). Controversy persists about whether screening and treating subclinical thyroid dysfunction is warranted $(1,5-7)$ because current evidence about the risks is limited $(1,5)$ and randomized, controlled trials on relevant clinical outcomes have not been done $(5,8)$.

Subclinical hypothyroidism has been associated with elevated cholesterol levels (9-11) and increased risk for atherosclerosis $(12,13)$. Yet, data on the relationship between subclinical hypothyroidism and coronary heart disease (CHD) events are conflicting $(12,14-17)$. In a previous meta-analysis (18), we found that subclinical hypothyroidism was associated with a 1.65 -fold increased risk (CI, 1.28 to 2.12) for CHD. However, that metaanalysis included several cross-sectional and case-control studies and only 5 small prospective studies. Recently, 3 large prospective studies on this issue have been published $(14,16,17)$, with somewhat inconsistent results. Because these new data include many additional CHD events, data are now sufficient to do a meta-analysis that includes only prospective studies, which provide greater validity. Data on

832 $(2008$ American College of Physicians the association between subclinical hypothyroidism and mortality are also conflicting $(14,17,19,20)$.

The consequences of subclinical hyperthyroidism have been less frequently studied than those of subclinical hypothyroidism. Subclinical hyperthyroidism has been associated with cardiovascular and total mortality (15), but with conflicting data $(14,17)$. Two of the 3 recent, large prospective studies $(14,17)$ also examined CHD and mortality in subclinical hyperthyroid participants. To summarize prospective evidence about the relationship between subclinical thyroid dysfunction and CHD and mortality, we did a systematic review of prospective cohort studies.

See also:

\section{Print}

Editors' Notes . . . . . . . . . . . . . . . . . 833

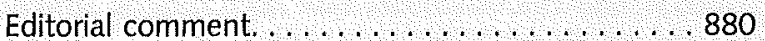

\section{Web-Only}

Appendix Tables

CME quiz

Conversion of graphics into slides

Audio summary 


\section{Context}

Is subclinical thyroid dysfunction associated with increased risk for coronary heart disease and mortality?

\section{Contribution}

This systematic review of 12 prospective cohort studies found that both subclinical hypothyroidism and hyperthyroidism were possibly associated with a small increased risk for coronary heart disease and mortality.

\section{Caution}

Data were uncertain. Confidence intervals around risk estimates were wide, particularly for those related to subclinical hyperthyroidism. Higher-quality studies showed lower estimates of risk than lower-quality studies

\section{Implication}

Randomized trials testing the efficacy of thyroxine replacement and antithyroid medications for subclinical hypothyroidism and subclinical hyperthyroidism are needed.

- The Editors

\section{METHODS}

We followed a standardized protocol and conducted and reported this analysis according to the guidelines of the Meta-analysis Of Observational Studies in Epidemiology group (21).

\section{Data Sources and Searches}

We conducted a systematic literature search of MEDLINE for articles in any language on the association between subclinical thyroid dysfunction (both subclinical hypothyroidism and hyperthyroidism) and CHD or mortality (cardiovascular and total) published from 1950 to January 2008. To avoid missing any relevant study, we also searched the bibliographies of key articles in the field and those included in this review. We did our search on an Ovid (MEDLINE) server by using broadly defined Medical Subject Headings, such as thyroid diseases, bypothyroidism, byperthyroidism, thyroid hormones, thyrotropin, mortality, myocardial ischemia, survival, and cardiovascular diseases and such keywords as subclinical bypothyroidism, subclinical byperthyroidism, subclinical dystbyroidism, and subclinical thyroid, combined with the filter designed by knowledge information specialists from $B M J$ to select prospective studies (MEDLINE cohort-study filter) (22) but without their year limitation.

\section{Study Selection}

Two reviewers independently screened the abstracts and titles of the search results and eliminated articles only if they did not clearly study the association between subclinical thyroid dysfunction and CHD or mortality (cardiovascular or total) in a prospective design. The same 2 re- viewers independently evaluated the remaining full-text articles for eligibility on the basis of a predefined set of eligibility criteria. Disagreements were resolved by consensus. We included only full-text, published, longitudinal cohort studies that measured thyroid function and followed persons prospectively, assessed CHD or mortality, and provided risk estimates or sufficient data to calculate risk estimates associated with subclinical thyroid dysfunction compared with normal thyroid function. Subclinical hypothyroidism was defined as elevated TSH levels and normal $\mathrm{T}_{4}$ levels (1). Several reviews suggest a TSH upper limit cutoff of 4.5 to $5.0 \mathrm{mU} / \mathrm{L}(1,5)$, but others suggest decreasing the upper limit of the TSH range to 2.5 to 3.0 $\mathrm{mU} / \mathrm{L}(23,24)$. In the absence of consensus, we did not prespecify a TSH cutoff value to define subclinical hypothyroidism and did a sensitivity analysis by limiting the analysis to studies with a TSH cutoff of $4.5 \mathrm{mU} / \mathrm{L}$ or greater (5). Because most adults with elevated TSH levels have subclinical and not overt hypothyroidism (2), we included 2 studies with participants who had elevated TSH levels without a $\mathrm{T}_{4}$ measurement report $(25,26)$ and did a sensitivity analysis excluding those studies.

For subclinical hyperthyroidism, we did not specify a TSH cutoff value (in the absence of consensus), but all studies had a cutoff value close to 0.3 to $0.5 \mathrm{mU} / \mathrm{L}$. We included 1 study with participants who had low TSH levels without a reported $\mathrm{T}_{4}$ measurement (26) and did a sensitivity analysis excluding this study. For CHD, we considered myocardial infarction, angina, the acute coronary syndrome, revascularization (coronary artery surgery, percutaneous transluminal coronary angioplasty), and significant coronary stenosis (defined as $\geq 50 \%$ ) (27). We also considered death due to CHD or cardiovascular disease and did a sensitivity analysis excluding studies that only included the latter. We assessed methods and criteria used for adjudication of those outcomes.

The agreement between the 2 reviewers was $99.5 \%$ for the first screen (titles and abstracts; $\kappa=0.79$ ) and $100 \%$ for the full-text screen $(\kappa=1.00)$.

\section{Data Extraction and Quality Assessment}

Two reviewers independently abstracted data on participant characteristics, criteria used to define subclinical thyroid dysfunction, CHD and mortality data, and study results with adjustment factors by using a standardized data collection form. Discrepancies in data extraction between reviewers were resolved by consensus. We systematically assessed key indicators of study quality (28): methods of outcome adjudication and ascertainment that account for confounders and completeness of follow-up ascertainment. Similar to our previous meta-analysis (18), study populations were considered either a convenience or a populationbased sample (defined as a random sample of the general population) (29). Methods of outcome adjudication were categorized as use of formal adjudication procedures and adjudication without knowledge of thyroid status. A for-

3 June $2008 \mid$ Annals of Intenal Medicine $\mid$ Volume 148 - Number $11 \mid \mathbf{8 3 3}$ 
REVIEW Subclinical Thyroid Dysfunction and Coronary Heart Disease or Mortality

Table 1. Population-Based Studies of Subclinical Thyroid Dysfunction and Risk for CHD and Mortality*

\begin{tabular}{lllll}
\hline Study, Year (Reference) & Sample & Mean Age & Women, & Follow-up \\
\cline { 2 - 4 } & (Range or SD), y & Duration
\end{tabular}

\section{Subclinical hypothyroidism \\ Population-based studies $\neq$ \\ Aho et al., 1984 (25) \\ Vanderpump et al., 1996 (30) (Whickham study)}

Hak et al., 2000 (12)

(Rotterdam study)

Parle et al., 2001 (15)

\begin{abstract}
Imaizumi et al. 2004 (20) (Nagasaki Adult Health Study)

Gussekloo et al., 2004 (19) (Leiden 85-plus Study)

Rodondi et al., 2005 (16) (Health, Aging, and Body Composition Study)
\end{abstract}

Walsh et al., 2005 (17) (Busselton Health

Study)

Cappola et al,

2006 (14)

(Cardiovascular

Health Study)

Bauer et al., 2007 (26)

(Study of

Osteoporotic

Fractures)

Convenience sample

lervasi et al., 2007 (31)

\author{
280 men from rural areas of eastern and southwestern Finland \\ 478 adults from mixed urban and rural areas near Newcastle, \\ United Kingdom* * \\ 957 women living in a district in Rotterdam, the Netherlands \\ 1171 community-dwelling adults in Birmingham, United \\ Kingdom
}

$\begin{array}{lcccc}64.5(55-74) \xi & 0 & 1974 & 5 y \\ 46(18-95) & 55.3 & 1972-1974 & 20 y \\ & & & \\ & & & \\ 69(-55) & 100 & 1990-1993 & 4.6 y\end{array}$

\begin{abstract}
999 atomic bomb survivors in Nagasak, Japan 2550 atomic bomb survivors in Nagasaki, Japan 999 atomic bomb survivors in Nagasaki, Japan

\section{$58(10)$ \\ $58(10)$ \\ $58(10)$} 558 adults living in 1 urban district in Leiden, the Netherlands

2730 community -dwelling adults in areas surrounding Pittsburgh, Pennsylvania, and Memphis, Tennessee

85

\begin{abstract}
18
\end{abstract}
1926 adults living in Busselton, Western Australia

3233 community-dwelling adults in 4 U,S, communities Washington County, Maryland, Allegheny County, Pennsylvania, Sacramento County, California, and Forsyth County, North Carolina

487 community-dwelling women in 4 U.S. communities:

Portland, Oregon; Minneapolis, Minnesota; Baltimore,

Maryland; and the Monongahela Valley, Pennsylvanial| \|
$747(70-79)$

$49.8(17-89)$

$72.7(\geq 65)$

$71.7(\geq 65)$

100

\begin{tabular}{|c|c|}
\hline 0 & $1984-1987$ \\
\hline 608 & 1984 \\
\hline 0 & 198 \\
\hline 66 & 1997 \\
\hline
\end{tabular}

$6 y$

$10 y$

$6 y$

$3.7 y$

3121 patients admitted to 1 cardiology department (Pisa,
(taly), excluding those with ACS or severe illness

$61,1607-615)$

32.6

$2000-2006$

2.7 y

Subclinical hyperthyroidism

Population-based studies Parle et al., 2001 (15)
1171 community-dwelling adults in Birmingham, United Kingdom

$70.4(>60)$

57.2

$1988-1989$

$8.2 y$ mal adjudication procedure was defined as having clear criteria for the outcomes that were reviewed by experts for each potential case (29) (for example, specific electrocardiogram or cardiac enzyme modifications for CHD). We did not consider CHD adjudication based only on death certificates as a formal adjudication procedure. If an article did not clearly mention 1 of these criteria, we considered that it had not been done.

We contacted the authors of 7 studies $(12,14,15,19$, $26,30,31)$ that met inclusion criteria but did not provide 834 3 June 2008|Anmals of Internal Medicine Volume $148 \cdot$ Number 11 specific data on the associations between subclinical thyroid dysfunction and CHD or mortality. We obtained risk estimates and CIs for cardiovascular and total mortality from cohort studies in the United Kingdom (15) and the Netherlands (19), as well as specific data for CHD mortality from a cohort of cardiac patients in Italy (31). Authors of a cohort study that published data about the relationship between autoimmune thyroid disease and CHD (30) provided us with data specific to subclinical hypothyroidism that were available for a subgroup of the participants. 
Table 1 - Continued

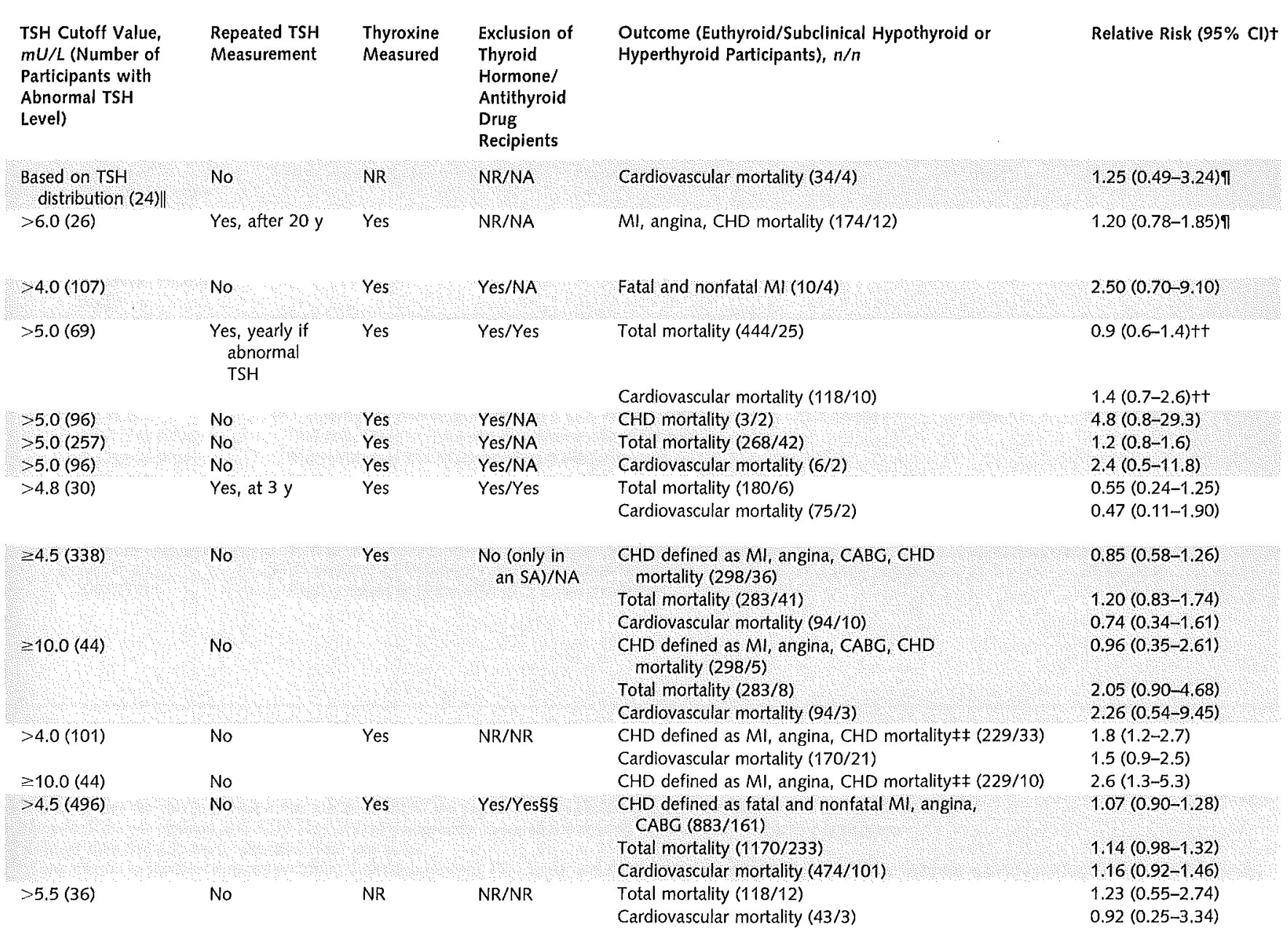

\begin{tabular}{|c|c|c|c|c|c|}
\hline $4.5-10.0(208)$ & $\begin{array}{l}\text { Yes, within } 3 \\
\text { mo to } \\
\text { exclude } \\
\text { transient } \\
\text { dysfunction }\end{array}$ & Yes & Yes/Yes & $\begin{array}{l}\text { Total mortality }(140 / 27) \\
\mathrm{CHD} \text { mortality }(48 / 12)\end{array}$ & $\begin{array}{l}2.01(1,33-3.04) \\
2.58(1,38-4.87)\end{array}$ \\
\hline$<0.44(76)$ & $\begin{array}{l}\text { Yes, yearly if } \\
\text { abnormal } \\
\text { TSH }\end{array}$ & Yes & Yes/Yes & $\begin{array}{l}\text { Total mortality (444/33) } \\
\text { Cardiovascular mortality }(118 / 11)\end{array}$ & $\begin{array}{l}1.2(0.9-1.8)++ \\
1.6(0.8-2.9)+t\end{array}$ \\
\hline
\end{tabular}

Three studies provided us with specific numbers of outcomes in each thyroid group $(12,14,26)$.

We used the most adjusted risk estimates available (the model containing the greatest number of covariates), unless a separate model further adjusted for thyroid antibodies, because thyroid autoimmunity has been hypothesized to be a mediator in the association between subclinical hypothyroidism and CHD (20). We did a sensitivity analysis without the studies that ad- justed for cholesterol because high cholesterol might be on the causal pathway. When risk estimates and CIs were not provided but raw data were available $(25,30$, 32), we calculated relative risks (RRs) and CIs by using the Woolf method (33-35).

\section{Data Synthesis and Analysis}

We first qualitatively synthesized data, paying particular attention to which definitions of subclinical thyroid 3 June 2008 Annals of Internal Medicine $/$ Volume 148 - Number $11 \mid \mathbf{8 3 5}$ 


\section{Table 1-Continued}

Study, Year (Reference) Sample

Mean Age Women

(Range or SD), $y$
Women
Follow-up

Initial
Gussekloo et al, 2004 (19) (Leiden 85-plus Study)

Walsh et al., 2005 (17) (Busselton Health

Study)

Cappola et als, $2006(14)$ (Cardiovascula Health Study)

Bauer et al., 2007 (26) (Study of Osteoporotic Fractures)

Conventence sample

Radácsl et al, $2003(32)$

lervasi et al. 2007 (31)
558 adults living in 1 urban district in Leiden, the Netherlands

1926 adults living in Busselton, Western Australia

3233 community dwelling adults in 4 US communities Washington County, Maryland, Allegheny County, Pennsylvania, Sacramento County, California, and Forsyth County, North Carolina

487 community-dwelling women in 4 U.S. communities: Portland, Oregon; Minneapolis, Minnesota; Baltimore, Maryland; and the Monongahela Valley, Pennsylvania||l

93 patients with a history of stroke or hip replacement undergoing rehabilitation at a geriatric hospital in Hungary 3121 patients admitted to 1 cardiology department (Pisa, Italy), excluding those with ACS or severe illness

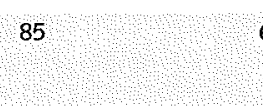

$49.8(17-89)$

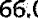

49.6

$3.7 \mathrm{y}$

$20 y$

1981

$1989-1990$

$12.5 y$

727 ( 65

596

$71.7(\geq 65)$

100

$1986-1988$

$11.9 y$

$\begin{array}{ccc}77(64-87) & 64.5 & \mathrm{NR} \\ 61.1(60.7-61.5) & 32.6 & 2000-2006\end{array}$

$2 y$

$2.7 \mathrm{y}$

\footnotetext{
${ }^{*} \mathrm{ACS}=$ acute coronary syndrome; $\mathrm{CABG}=$ coronary artery bypass graft; $\mathrm{CHD}=$ coronary heart disease; $\mathrm{MI}=$ myocardial infarction; $\mathrm{NA}=$ not applicable; $\mathrm{NR}=$ nor reported; $\mathrm{SA}=$ sensitivity analysis; $\mathrm{TSH}=$ thyroid-stimulating hormone.

+ Relative risks were estimated on the basis of hazard ratios in 8 studies $(14-17,19,20,26,31)$.

$¥$ A population-based study was defined as a random sample of the general population.

$\S$ The mean age for this population was not available in the article or from the authors and was assumed to be age 64.5 years.

$\|$ Elevated TSH was defined as a TSH level $>2$ SDs above the mean of the thyroid autoantibody $m$ negative participants.

II Relative risks and Cls were calculated from raw data.

* Data specific to subclinical hypothyroidism, defined as elevated TSH levels, and the development of CHD were available from the authors only for a subgroup of the study.

t+ Study authors provided relative risk for subclinical hypothyroidism after exclusion of 18 participants with low thyroxine levels and relative risk for subclinical hyperthyroidism after exclusion of 2 participants with high thyroxine levels.

¥¥ Coronary heart disease events were defined as death from CHD or hospital admission with a diagnosis of CHD (International Classification of Diseases, Ninth Revision, Clinical Modification, codes $410-414)$.

$\S \S$ This study also accounted for thyroid hormone use during follow-up, analyzing it as a time-dependant covariate.

III Nested sample of the overall cohort.
}

dysfunction were used and which outcomes were measured. To calculate summary estimates and CIs of the risk for subclinical thyroid dysfunction, we pooled both RRs and hazard ratios (HRs) by using random-effects models based on the variance model developed by DerSimonian and Laird (36). Analyses were repeated by using fixedeffects models for comparison. The presence of heterogeneity across studies was evaluated by using the $Q$ statistic with a conservative $P$ value of 0.10 (37). We also calculated the $I^{2}$ statistic, which describes the total variation across studies attributable to heterogeneity rather than chance; an $I^{2}$ value greater than $50 \%$ indicated at least moderate statistical heterogeneity (38). To explore sources of heterogeneity, we did several predefined sensitivity and subgroup analyses, all with a random-effects model. Given the recent findings of a possible protective effect of subclinical hypothyroidism in very elderly persons $(19,39)$, we conducted stratified analyses by mean age of the studied populations by using various cutoff values (age $<65$ years or $\geq 65$ years, and age $<60$ years, 60 to 79.9 years, or $\geq 80$ years). We also repeated the meta-analysis after limiting the analysis to multiply adjusted studies, studies with a TSH cutoff value of $4.5 \mathrm{mU} / \mathrm{L}$ or greater or $10.0 \mathrm{mU} / \mathrm{L}$ or greater (5), studies using formal adjudication procedures, and studies that excluded thyroid hormone or antithyroid drug recipients. Finally, we did an influence analysis to assess the effect of individual studies on the summary estimates $(40,41)$.

We used the Egger test (42) and funnel plots to help assess the possibility of publication bias. We conducted all statistical analyses by using STATA software, version 9.2 (Stata, College Station, Texas).

\section{Role of the Funding Source}

The Department of Ambulatory Care and Community Medicine and the Institute of Social and Preventive Medicine of the University of Lausanne, Lausanne, Switzerland, funded this study. The funding source had no role in defining questions, abstracting data, synthesizing results, 


\begin{tabular}{|c|c|c|c|c|c|}
\hline $\begin{array}{l}\text { TSH Cutoff Value, } \\
m U / L \text { (Number of } \\
\text { Participants with } \\
\text { abnormal TSH } \\
\text { Level) }\end{array}$ & $\begin{array}{l}\text { Repeated } \\
\text { TSH } \\
\text { Measurement }\end{array}$ & $\begin{array}{l}\text { Thyroxine } \\
\text { Measured }\end{array}$ & $\begin{array}{l}\text { Exclusion of } \\
\text { Thyroid } \\
\text { Hormone/ } \\
\text { Antithyroid } \\
\text { Drug } \\
\text { Recipients }\end{array}$ & $\begin{array}{l}\text { Outcome (Euthyroid/Subclinical Hypothyroid or } \\
\text { Hyperthyroid Participants), } n\end{array}$ & $\begin{array}{l}\text { Relative Risk }(95 \% \\
\text { Cl)t }\end{array}$ \\
\hline$<0.3(17)$ & Yes, at 3 y & Yes & Yes/Yes & Total mortality $(180 / 7)$ Cardiovascular mortality $(75 / 3)$ & $\begin{array}{l}1.20(0.59-2.69) \\
1.38(0.43-4.39)\end{array}$ \\
\hline$<0.4(37)$ & No & Yes & NR/NR & $\begin{array}{l}\text { CHD defined as MI, angina, CHD mortality } \neq \neq(229 / 5) \\
\text { Cardiovascular mortality }(170 / 3)\end{array}$ & $\begin{array}{l}1.3(0.6-3.3) \\
1.0(0.2-4.3)\end{array}$ \\
\hline$<0.45(47)$ & No & Yes & Yes/Yes\$5 & $\begin{array}{l}\text { CHD defined as fatal and nonfatal Ml, angina, } \\
\text { CABG }(883 / 18) \text {, } \\
\text { Total mortality }(1170 / 24) \\
\text { Cardiovascular mortality }(474 / 9)\end{array}$ & $\begin{array}{l}1.04(0.64-1.69) \\
1.08(0.72-1,62) \\
0.94(0.49-1,83)\end{array}$ \\
\hline$\leq 0.5(53)$ & No & NR & NR/NR & $\begin{array}{l}\text { Total mortality }(118 / 17) \\
\text { Cardiovascular mortality }(43 / 7)\end{array}$ & $\begin{array}{l}0.86(0.39-1.87) \\
0.91(0.28-2.95)\end{array}$ \\
\hline$<0.5(21)$ & Yes, at 2 y & Yes & $\mathrm{NR} / \mathrm{NR}$ & Total mortality $(18 / 10)$ & $1.69(0.93-3.07) 9$ \\
\hline$<0.3(98)$ & $\begin{array}{l}\text { Repeated } \\
\text { within } 3 \\
\text { mo to } \\
\text { exclude } \\
\text { transient } \\
\text { dysfunction }\end{array}$ & Yes & Yes/Yes & $\begin{array}{l}\text { Total mortality }(140 / 9) \\
\text { CHD mortality }(48 / 7)\end{array}$ & $\begin{array}{l}1.22(0.62-2.40) \\
2.67(1.20-5.92)\end{array}$ \\
\hline
\end{tabular}

preparing the manuscript, or deciding to submit the manuscript for publication.

\section{RESULTS}

\section{Study Selection}

Of the 2109 reports identified, we excluded 2077 studies that were unrelated to the association between subclinical thyroid dysfunction and CHD or mortality and 20 after detailed evaluation. Figure 1 shows details of the study selection. When similar data were published twice $(19,62)$, we included the original article with the most definitive and extractable form (19). Twelve prospective studies met eligibility criteria. Ten studies were population-based studies and included 14449 community-living adults without substantive comorbid conditions. Two were convenience samples of patients with specific diseases: cardiac patients (31) or patients with a history of stroke or hip replacement (32). Given the clinical heterogeneity between these 2 types of studies, we pooled the 10 population-based studies as the core of this analysis and examined the addition of the 2 convenience samples in subsidiary analyses. All 10 of the population-based studies examined subclinical hypothyroidism, and 5 also examined subclinical hyperthyroidism.

\section{Description and Quality of Studies}

Table 1 shows the study characteristics and the effect of subclinical hypothyroidism and hyperthyroidism on the risk for CHD and cardiovascular and total mortality. Participants were mostly middle-aged or older men and women. Follow-up ranged from 2 to 20 years. All studies used standard assays for thyroid function (63), with TSH cutoff values of 4.0 to $6.0 \mathrm{mU} / \mathrm{L}$ for subclinical hypothyroidism and 0.3 to $0.5 \mathrm{mU} / \mathrm{L}$ for subclinical hyperthyroidism. Only the 2 convenience samples of patients were specifically designed to evaluate associations between thyroid function and CHD or mortality $(31,32)$. Three studies repeated assessments of thyroid function before the end of

3 June $2008 \mid$ Annals of Internal Medicine $\mid$ Volume $148 \cdot$ Number $11 \mid \mathbf{8 3 7}$ 
Figure 1. Study flow diagram.

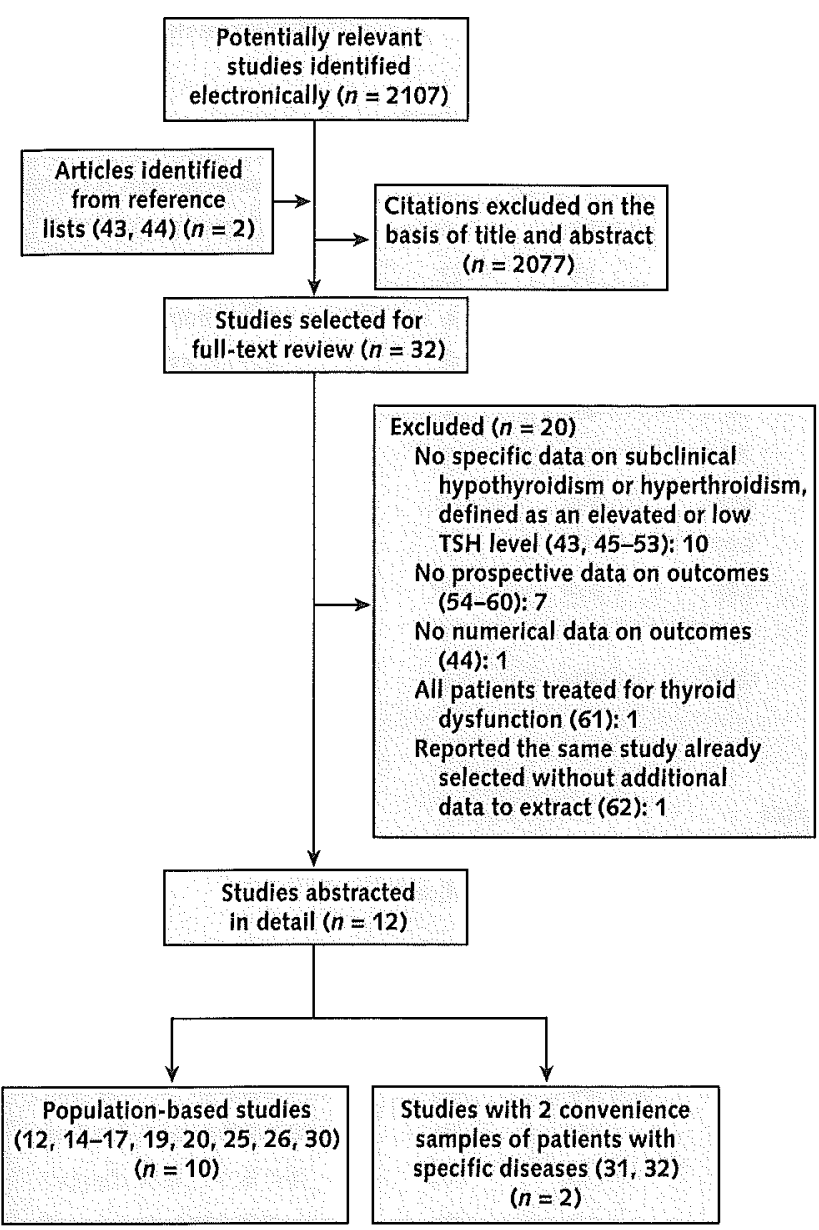

$\mathrm{TSH}=$ thyroid-stimulating hormone.

the follow-up $(15,19,31)$, and 7 excluded persons treated with thyroid hormone.

Study quality was heterogeneous. Five studies reported formal adjudication procedures, and 8 adjudicated outcomes without knowledge of thyroid status (Appendix Table 1, available at www.annals.org). If an article did not clearly mention 1 of these characteristics, we considered it not to have been done. When reported, $5 \%$ or fewer participants in most studies were lost to followup. Only 4 studies adjusted for most cardiovascular risk factors, and several studies adjusted for only a few confounding factors.

\section{Subclinical Hypothyroidism and CHD}

Several studies suggested that subclinical hypothyroidism was associated with a small increased risk for $\mathrm{CHD}$; only 1 of these (17) had statistically significant findings (Figure 2). In a random-effects model, the summary RR of $\mathrm{CHD}$ associated with subclinical hypothyroidism was 1.20 (CI, 0.97 to 1.49) for 2134 CHD events, with weak evidence of heterogeneity $\left(P\right.$ for heterogeneity $=0.14 ; I^{2}=$
33.4\%) (Table 2). Studies that adjusted for cardiovascular risk factors yielded similar results. The summary $R R$ was 1.02 for the 5 studies that used formal adjudication procedures and 1.08 for the 8 studies that adjudicated outcomes without knowledge of thyroid status. The 3 studies (14, $16,19)$ that met most of our quality criteria (Appendix Table 1, available at www.annals.org) -all conducted in older adults - had point estimates less than or close to 1.0 (1.07 in the study by Cappola and colleagues [14]). In subgroup analysis by age, the summary RR was 1.51 for studies whose samples had mean age younger than 65 years and 1.05 for studies whose samples had a mean age 65 years or older. Compared with the overall random-effects model, these subgroup analyses had lower heterogeneity $(P$ for heterogeneity $=0.32$ to $0.42 ; I^{2}=0.0 \%$ to $15.4 \%$ ). Using other age cutoff levels revealed a similar pattern.

Excluding 2 studies that did not report $\mathrm{T}_{4}$ measurement (with the possible inclusion of some participants with overt hypothyroidism), those that included thyroid hormone recipients, or those that included cardiovascular death instead of CHD as outcomes yielded similar results (data not shown). The RR of the pooled estimates from the 2 studies that gave data for a TSH cutoff value of 10.0 $\mathrm{mU} / \mathrm{L}$ or higher was 1.69 (CI, 0.64 to 4.45 ). Because data specific to subclinical hypothyroidism were available only for a subgroup in the study by Vanderpump and colleagues (30), we did a sensitivity analysis including all participants that showed a pooled RR of 1.18 (CI, 0.96 to 1.46 ).

\section{Subclinical Hypothyroidism and Total and Cardiovascular Mortality}

Several studies demonstrated a pattern of increased risk for total or cardiovascular mortality associated with subclinical hypothyroidism (Figure 2). For 2822 deaths, the summary RR was $1.12(\mathrm{CI}, 0.99$ to 1.26$)$ for total mortality and 1.18 (CI, 0.98 to $1.42 ; P$ for heterogeneity $>0.50$ for both; $I^{2}=0 \%$ ) for 1167 cardiovascular deaths. Most sensitivity analyses yielded similar results (Appendix Tables 2 and 3, available at www.annals.org). For cardiovascular mortality, pooling studies in which the mean age of participants was less than 65 years yielded an RR of 1.50 ; the $R R$ was 1.12 if participants were 65 years or older. However, this analysis should be considered with caution because of the small number of studies.

\section{Subclinical Hyperthyroidism and CHD}

Several studies demonstrated a pattern of an increased risk for CHD associated with subclinical hyperthyroidism (Figure 3), with a summary RR of 1.21 (CI, 0.88 to 1.68 ; $P$ for heterogeneity $=0.85 ; I^{2}=0 \%$ ) for $1392 \mathrm{CHD}$ events. Most sensitivity analyses yielded similar results (Table 3), except for lower point estimates when 2 studies with adjustment for most cardiovascular risk factors (RR, 1.10) and 3 studies with formal adjudication procedures (RR, 1.06) were pooled. We found no differences by mean age. 
Figure 2. Forest plots for subclinical hypothyroidism.

Study, Year (Reference)

Coronary heart disease

Aho et al., 1984 (25)

Vanderpump et al., 1996 (30)

Hak et al., 2000 (12)

Parle et al., 2001 (15)

Imaizumi et al., 2004 (20)

Gussekloo et al., 2004 (19)

Rodondi et al., 2005 (16)

Walsh et al., 2005 (17)

Cappola et al., 2006 (14)

Bauer et al, 2007 (26)

Total $\left(/^{2}=33.4 \% ; P=0.140\right)$

Study, Year (Reference)

Total mortality

Parle et al., 2001 (15)

Imaizumi et al., 2004 (20)

Gussekloo et al., 2004 (19)

Rodondi et al., 2005 (16)

Cappola et al., 2006 (14)

Bauer et al., 2007 (26)

Total $\left(l^{2}=0.0 \% ; P=0.51\right)$

Study, Year (Reference)

Cardiovascular mortality

Aho et al., 1984 (25)

Parle et al., 2001 (15)

Imaizumi et al., 2004 (20)

Gussekloo et al., 2004 (19)

Rodondi et al., 2005 (16)

Walsh et al., 2005 (17)

Cappola et al., 2006 (14)

Bauer et al., 2007 (26)

Total $\left(I^{2}=0.0 \% ; P=0.65\right)$

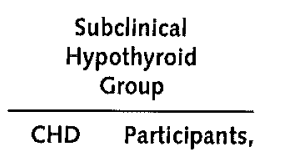

\begin{tabular}{cc}
\multicolumn{2}{c}{$\begin{array}{c}\text { Euthyroid } \\
\text { Group }\end{array}$} \\
\hline $\begin{array}{cc}\text { CHD } \\
\text { Events, } n\end{array}$ & Participants, \\
& $n$
\end{tabular}

Events, $n \quad n$

$\begin{array}{cc}4 & 24 \\ 12 & 26 \\ 4 & 107 \\ 10 & 76 \\ 2 & 257 \\ 2 & 30 \\ 36 & 338 \\ 33 & 101 \\ 161 & 496 \\ 3 & 36 \\ 267 & 1491\end{array}$

$\begin{array}{cc}34 & 256 \\ 174 & 452 \\ 10 & 850 \\ 118 & 1026 \\ 3 & 2293 \\ 75 & 472 \\ 298 & 2392 \\ 229 & 1752 \\ 883 & 2639 \\ 43 & 398 \\ 1867 & 12530\end{array}$

Subclinical Hypothyroid Group

Deaths, $n$ Participants, $\overline{\text { Deaths, } n \text { Participants, }}$

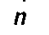

$\begin{array}{cccc}25 & 76 & 444 & 1026 \\ 42 & 257 & 268 & 2293 \\ 6 & 30 & 180 & 472 \\ 41 & 338 & 283 & 2392 \\ 233 & 496 & 1170 & 2639 \\ 12 & 36 & 118 & 398 \\ 359 & 1233 & 2463 & 9220\end{array}$

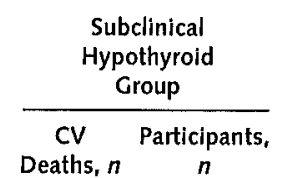

\begin{tabular}{cc}
\multicolumn{3}{c}{$\begin{array}{c}\text { Euthyroid } \\
\text { Group }\end{array}$} \\
\hline CV & Participants, \\
Deaths, $n$ & $n$
\end{tabular}
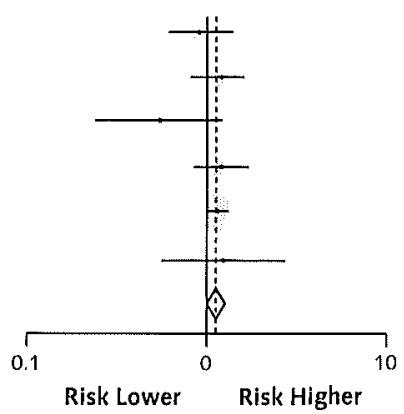

Deaths, $n \quad n$

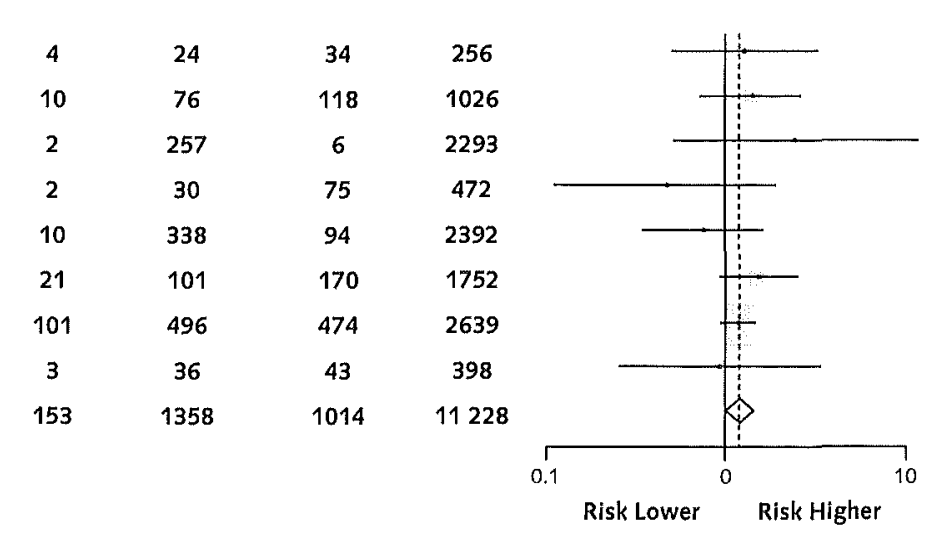

Relative Risk $(95 \% \mathrm{Cl})$

Weight,

$\%$

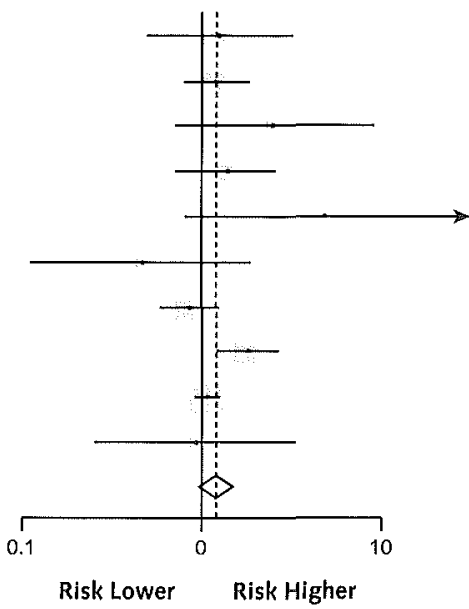

$1.25(0.49-3.24)$

4.65

$1.20(0.78-1.85) \quad 15.06$

$2.50(0.70-9.10) \quad 2.68$

$1.40(0.70-2.60) \quad 8.49$

$4.80(0.80-29.30) \quad 1.41$

$0.47(0.11-1.90) \quad 2.20$

$0.85(0.58-1.26) \quad 17.00$

$1.80(1.20-2.70) \quad 16.19$

$1.07(0.90-1.28) \quad 29.69$

$0.92(0.25-3.34) \quad 2.63$

$1.20(0.97-1.49) \quad 100.00$

Relative Risk Weight,

$(95 \% \mathrm{Cl}) \quad \%$
$1.25(0.49-3.24) \quad 3.84$

$1.40(0.70-2.60) \quad 7.96$

$2.40(0.50-11.80) \quad 1.37$

$0.47(0.11-1.90) \quad 1.69$

$0.74(0.34-1.61) \quad 5.67$

$1.50(0.90-2.50) \quad 13.14$

$1.16(0.92-1.46) \quad 64.29$

$0.92(0.25-3.34) \quad 2.04$

$1.18(0.98-1.42) \quad 100.00$

The diamonds represent relative risks and the horizontal lines represent $95 \% \mathrm{CI}$ s of the effect of subclinical hypothyroidism. CHD $=$ coronary heart disease; $\mathrm{CV}=$ cardiovascular. 


\section{Subclinical Hyperthyroidism and Total and Cardiovascular Mortality}

The RR for total mortality was 1.12 (CI, 0.89 to 1.42 ) for 1993 deaths and 1.19 (CI, 0.81 to 1.76) for 913 cardiovascular deaths $(P$ for heterogeneity $>0.80$ for both; $I^{2}=0 \%$ ) (Figure 3 ). Most sensitivity analysis yielded similar results (Appendix Tables 4 and 5, available at www.annals.org), except for an RR of 0.95 for cardiovascular mortality (when 2 studies adjusted for most cardiovascular risk factors were pooled) and 1.01 for 3 studies with formal adjudication procedures.

\section{Additional Studies Not Included in the Primary Analyses}

For both subclinical hypothyroidism and hyperthyroidism, addition of the convenience samples of patients with specific diseases $(31,32)$ increased the point estimates for CHD and mortality (summary RRs, 1.18 to 1.55 [Tables 2 and 3; Appendix Tables 2, 3, 4, and 5, available at www.annals.org]). These summary RRs reached or were close to statistical significance but had increased statistical heterogeneity for all associations.

\section{Publication Bias Evaluation}

We found no evidence of publication bias, either with visual assessment of funnel plots (data not shown) or with the Egger test $(P>0.30$ for all associations). Because small negative studies are most subject to publication bias and some might be missing, we excluded studies with fewer than 500 participants and obtained similar estimates for all associations. Influence analysis indicated that the exclusion of single studies did not substantially alter any estimates (data not shown).

\section{DISCUSSION}

In the meta-analysis of 10 population-based prospective cohort studies, we found that subclinical thyroid dysfunction was associated with a pattern of modest increased risk for CHD and mortality (summary RRs, 1.12 to 1.21 ). Estimates about subclinical hyperthyroidism, which were derived from only 5 studies, had wider CIs than estimates for subclinical hypothyroidism. In general, we found lower risk estimates (RR, 1.01 to 1.21 ), when we pooled higherquality studies, such as those that used formal adjudication procedures for outcomes although the upper bound of the CIs for these estimates was still consistent with overall summary RRs of increased risk. The relationship between subclinical hypothyroidism and CHD seemed to differ among studies that involved middle-aged versus elderly participants, with studies whose samples had a mean age younger than 65 years showing increased risk for CHD. Subclinical hypothyroid participants with a TSH 10.0 $\mathrm{mU} / \mathrm{L}$ or greater might also have an increased CHD risk, but only 2 studies reported such stratified data. Risk estimates were higher when the 2 convenience samples of patients with specific diseases were added.

For the association between subclinical hypothyroid-

Table 2. Stratified Analysis of the Association of Subclinical Hypothyroidism with Risk for CHD*

\begin{tabular}{|c|c|c|}
\hline Characteristic & $\begin{array}{l}\text { Summary Relative Risk } \\
(95 \% \mathrm{CI}) \dagger\end{array}$ & $\begin{array}{l}\text { Studies, } \\
n\end{array}$ \\
\hline \multicolumn{3}{|l|}{ Eligible study model } \\
\hline Random effects. & $1.20(0.97-1.49)$ & 10 \\
\hline Fixed effects & $1.14(1.00-1.30)$ & 10 \\
\hline \multicolumn{3}{|l|}{ Study quality } \\
\hline Formal CHD or cardiovascular mortality rate adjudication procedures & $1.02(0.86-1.22)$ & 5 \\
\hline Adjudication without knowledge of thyroid status & $1.08(0.90-1.31)$ & 8 \\
\hline \multicolumn{3}{|l|}{ Stratified by mean age } \\
\hline$<65 y$ & $1.51(1.09-2.09)$ & 4 \\
\hline$\geq 65 y$ & $1.05(0.90-1.22)$ & 6 \\
\hline$<60 y$ & $1.58(1.02-2,43)$ & 3 \\
\hline $60-79.9$ y & $1.06(0.91-1.24)$ & 6 \\
\hline$\geq 80 y$ & $0.47(0.11-1.90)$ & 1. \\
\hline \multicolumn{3}{|l|}{ Adjustments } \\
\hline Adjusted analyses or matching & $1.21(0.93-1.58)$ & 9 \\
\hline Adjusted for cardovascular risk factors & $1.22(0.86-1.73)$ & 4 \\
\hline \multicolumn{3}{|l|}{ Definition of subclinical hypothyroidism } \\
\hline $\mathrm{TSH}$ level $\geq 4.5 \mathrm{mU} / \mathrm{L}$ & $1.06(0.91-1.25)$ & 7 \\
\hline $\mathrm{TSH}$ level $\geq 10.0 \mathrm{mU} / \mathrm{L}$ & $1.69(0,64-4.45)$ & 2 \\
\hline Particular population: elderly participants excluded (19) & $1.22(0.99-1.52)$ & 9 \\
\hline Subsidlary analysis, addition of a convenience sample of cardiac patients (31) & $1,31(1,02-1,67)+$ & 11 \\
\hline
\end{tabular}

* $\mathrm{CHD}=$ coronary heart disease; TSH $=$ thyroid-stimulating hormone.

+ Relative risk from meta-analysis using random-effects model.

$¥$ Addition of the convenience sample of cardiac patients increased overall statistical heterogeneity $\left(P\right.$ for heterogeneity $\left.=0.03 ; I^{2}=49.0 \%\right)$.

$840 \mid 3$ June $2008 \mid$ Annals of Internal Medicine $\mid$ Volume 148 - Number 11 
Figure 3. Forest plots for subclinical hyperthyroidism.

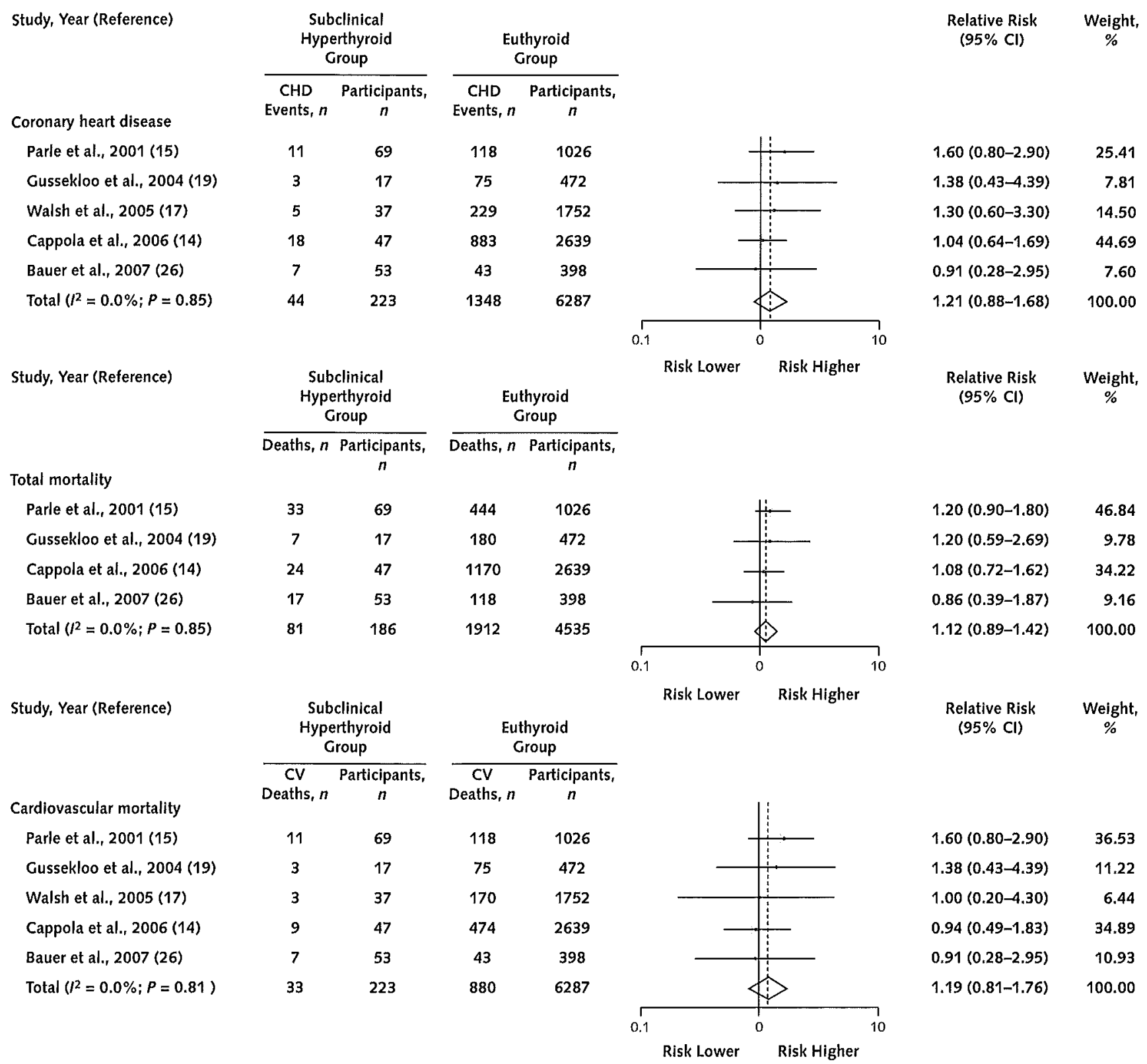

The diamonds represent relative risks and the horizontal lines represent $95 \% \mathrm{CI}$ s of the effect of subclinical hyperthyroidism. CHD $=$ coronary heart disease; $\mathrm{CV}=$ cardiovascular.

ism and CHD, several population-based studies yielded conflicting results. Two individual prospective studies found a statistically significant association between subclinical hypothyroidism and CHD: the Busselton Health Study (HR, 1.8) (17) and a sample of cardiac patients (HR, 2.58) (31). However, 2 large prospective cohort studies of older adults found no increased risk for CHD (14, 16). These 2 studies adjusted their results for most cardiovascular risk factors and met most of our quality criteria, whereas the 2 studies with substantial associations $(17,31)$ did not formally adjudicate cardiovascular outcomes or re- port whether adjudication was done without knowledge of thyroid status. A meta-analysis pooled only 3 recent studies $(14,16,17)$ and obtained a summary RR of 1.19 (CI, 1.02 to 1.38 ) (64), driven in part by the use of the unadjusted RR of 2.5 from the Busselton Health Study (adjusted HR, 1.8) (65). In our previous meta-analysis (18), we found a statistically significant association between subclinical hypothyroidism and CHD (summary odds ratio, $1.65[\mathrm{CI}$, 1.28 to 2.12$]$ ), but that analysis included 3 case-control and 6 cross-sectional studies. When our previous metaanalysis of subclinical hypothyroidism and CHD was lim-

3 June 2008 Annals of Internal Medicine $\mid$ Volume $148 \cdot$ Number $11 \mid \mathbf{8 4 1}$ 
REVIEW Subclinical Thyroid Dysfunction and Coronary Heart Disease or Mortality

Table 3. Stratified Analysis of the Association of Subclinical Hyperthyroidism with Risk for CHD*

\begin{tabular}{|c|c|c|}
\hline Characteristic & $\begin{array}{l}\text { Summary Relative Risk } \\
(95 \% \mathrm{Cl}) \dagger\end{array}$ & $\begin{array}{l}\text { Studies, } \\
n\end{array}$ \\
\hline \multicolumn{3}{|l|}{ Eligible study models } \\
\hline Random effects & $1.21(0.88-1.68)$ & 5 \\
\hline Fixed effects & $1.21(0.88-1.68)$ & 5 \\
\hline \multicolumn{3}{|l|}{ Study quality } \\
\hline Formal $\mathrm{CHD}$ or cardiovascular mortality rate adjudication procedures & $1.06(0.70-1.61)$ & 3 \\
\hline Adjudication without knowledge of thyroid status & $1.20(0.84-1.70)$ & 4 \\
\hline \multicolumn{3}{|l|}{ Stratified by mean age } \\
\hline$<65 y$ & $1.3(0.6-3.3)$ & 1 \\
\hline$\geq 65$ y & $1.20(0.84-1.70)$ & 4 \\
\hline$<60 y$ & $1.3(0.6-3.3)$ & 1 \\
\hline $60-79.9$ y & $1.18(0.82-1.71)$ & 3 \\
\hline$\geq 80$ y & $1.38(0.43-4.39)$ & 1 \\
\hline \multicolumn{3}{|l|}{ Adjustments } \\
\hline Adjusted analyses or matching & $1.21(0.88-1.68)$ & 5 \\
\hline Adjusted for cardiovascular risk factors & $1.10(0.72-168)$ & 2 \\
\hline Particular population: elderly participants excluded (19) & $1.20(0.86-1.68)$ & 4 \\
\hline Subsidiary analysis: addition of 2 convenience samples $(31,32)$ & $1.54(1.04-2,28) \neq$ & 7. \\
\hline
\end{tabular}

* $\mathrm{CHD}=$ coronary heart disease.

† Relative risk from meta-analysis using random-effects model.

$¥$ Addition of the 2 convenience samples increased overall statistical heterogeneity ( $P$ for heterogeneity $=0.17 ; I^{2}=34.2 \%$ ).

ited to the 5 older prospective cohort studies $(12,15,20$, $25,30)$ that were of lower quality than the more recent ones, the summary RR was 1.42 (CI, 0.91 to 2.21 ).

Our analyses showed a pattern of higher mortality rates in participants with subclinical hypothyroidism, consistent with 2 previous meta-analyses that found slightly higher risks (summary RRs, 1.25 and 1.21 [66] and 1.12 and 1.28 [64] for total and cardiovascular mortality, respectively). However, these older meta-analyses included only 4 studies with mortality outcomes $(14,16,17,20)$ and had some limitations, such as data extraction errors $(64,65)$ and lack of assessment of statistical heterogeneity or sensitivity analyses (66). Our results might not apply to all ages, because 1 study found an even lower risk for total mortality $(H R, 0.55)$ in adults age 85 years with subclinical hypothyroidism than in euthyroid participants (19).

Similar to a previous meta-analysis (66), we found a pattern of modestly increased risk for CHD and mortality associated with subclinical hyperthyroidism, with wider CIs than those for subclinical hypothyroidism, given the more limited data, and lower risk estimates when higherquality studies were pooled. Further large studies are needed to better assess these risks. The higher risks found in the 2 convenience samples of patients with specific diseases, particularly for subclinical hyperthyroidism, increase the likelihood that subclinical thyroid dysfunction associated with other diseases might be a different, potentially more harmful entity than subclinical thyroid dysfunction among healthier individuals or that sick patients might be less tolerant to abnormal levels of TSH. We previously found that associations between subclinical hypothyroidism and heart failure were stronger for recurrent than for incident events (16). However, these differences are based on only 2 prospective cohorts of patients with specific diseases and should be confirmed in other studies.

We found weak evidence for statistical heterogeneity among individual study findings, and age explained part of the heterogeneity for the association between subclinical hypothyroidism and $\mathrm{CHD}$, with an increased risk for CHD only in cohorts with a younger mean age. These potential age differences should be interpreted with caution, given the possibility of ecological fallacy without individual patient data (28). One cross-sectional study did subgroup analyses by age and found that the risk for CHD associated with subclinical hypothyroidism was higher in younger participants (67); however, no prospective study presented stratified analyses by age. Although this finding should be confirmed by stratified analyses in future prospective cohort studies with a wide age range, potential explanations for these age differences might be competing mortality among older adults (for example, due to cancer) or more competing risk factors for CHD among older adults (for example, age or sex). If the risk for CHD with subclinical hypothyroidism was mainly mediated by increased cholesterol levels, it might weaken with age because levels of total and low-density lipoprotein cholesterol are strong cardiovascular risk factors in middle-age but not older adults (68). Other potential explanations could be related to thyroid physiology in older adults (decreased thyroid hormone action at the tissue level, decreased thy- 
roid hormone metabolism) (39). High TSH levels in elderly persons might also be a compensatory mechanism for other perturbations, whereas in younger adults it is caused by thyroid dysfunction.

Our study has several limitations. First, a meta-analysis of observational studies should be interpreted with caution (69), even though it can provide useful information when only data from observational studies are available (21). To our knowledge, no randomized, controlled trial has studied the benefits of treating adults with subclinical thyroid dysfunction with regard to $\mathrm{CHD}$ or mortality $(5,8)$. We found only weak evidence for statistical heterogeneity among studies, but some clinical heterogeneity with slightly different TSH cutoff levels $(4.0$ to $6.0 \mathrm{mU} / \mathrm{L}$ for subclinical hypothyroidism and 0.3 to $0.5 \mathrm{mU} / \mathrm{L}$ for subclinical hyperthyroidism), varying CHD definitions, or different confounding factors included for adjustment. We could not assess the risk for specific CHD outcomes, such as MI or "hard" CHD (MI, coronary death) outcomes, because such subgroup analysis was lacking in most original studies. However, sensitivity analyses pooling more homogeneous studies yielded similar risk estimates, although such estimates were lower when higher-quality studies were pooled. Alternative explanations for observed results are bias in the selection of included studies, bias and quality problems in the original studies, publication bias, heterogeneity, and confounding (21).

To limit bias in the selection of included studies, we used broad inclusion criteria for studies that provided quantitative data on the risk for CHD or mortality associated with subclinical thyroid dysfunction and then did sensitivity analyses according to differences between the studies and methodological study quality, as recommended $(21,70)$. We could not exclude all participants with inadequately treated overt thyroid dysfunction or nonthyroidal illness (71) because these subgroup data were lacking in the original studies. Subgroup analyses should be interpreted with caution given the limited number of studies. Although our graphical and statistical analyses showed that publication bias was unlikely, it cannot be excluded because the capacity to detect publication bias is reduced when meta-analyses are based on a limited number of studies $(42,72)$. Selective reporting of the outcomes in the cohorts cannot be excluded, either.

In summary, our data suggest that subclinical thyroid dysfunction might represent a potentially modifiablealbeit modest-risk factor for CHD and mortality. Assuming that treatment is effective, given the high prevalence of thyroid disease even a small increase in CHD or mortality rates among persons with subclinical dysfunction (such as the $10 \%$ to $20 \%$ increased RR in our study) would have public health implications. From a health policy perspective, it would be premature to recommend screening for thyroid dysfunction in the general population. Given the pattern of modestly increased risk for CHD and mortality associated with subclinical thyroid dysfunction, lower risk estimates in higher-quality studies, and the remaining uncertainty, treatment of subclinical thyroid dysfunction with $\mathrm{CHD}$ as an end point should be studied in randomized, placebo-controlled trials to assess the efficacy of $T_{4}$ replacement or antithyroid medications before current recommendations are updated $(1,5)$.

From University of Lausanne, Lausanne, Switzerland; University of California, San Francisco, San Francisco, California; and Leiden University Medical Center, Leiden, the Netherlands.

Acknowledgment: The authors thank Professor Jayne A. Franklyn (University of Birmingham, Birmingham, United Kingdom), Professor Anne R. Cappola (University of Pennsylvania, Philadelphia, Pennsylvania), Dr. Alice M. Arnold (University of Washington, Seattle, Washington), Dr. Patrick Maisonneuve (European Institute of Oncology, Milan, Italy), Dr. Mark Vanderpump (Royal Free Hampstead NHS Trust, Hampstead, United Kingdom), Professor Mike Tunbridge (Oxford Radcliffe Hospitals, Oxford, United Kingdom), Dr. Iervasi (Clinical Physiology Institute, Pisa, Italy) and Dr. Hak (Erasmus MC University Medical Center, Rotterdam, the Netherlands) for their assistance and for supplying additional data from their studies.

Potential Financial Conflicts of Interest: None disclosed.

Requests for Single Reprints: Nicolas Rodondi, MD, MAS, Department of Ambulatory Care and Community Medicine, University of Lausanne, Bugnon 44, 1011 Lausanne, Switzerland; e-mail, nicolas.rodondi @hospvd.ch.

Current author addresses are available at www.annals.org.

\section{References}

1. Helfand M. U.S. Preventive Services Task Force. Screening for subclinical thyroid dysfunction in nonpregnant adults: a summary of the evidence for the U.S. Preventive Services Task Force. Ann Intern Med. 2004;140:128-41. [PMID: 14734337]

2. Hollowell JG, Staehling NW, Flanders WD, Hannon WH, Gunter EW, Spencer CA, et al. Serum TSH, T(4), and thyroid antibodies in the United States population (1988 to 1994): National Health and Nutrition Examination Survey (NHANES III). J Clin Endocrinol Metab. 2002;87:489-99. [PMID: 11836274] 3. Parle JV, Franklyn JA, Cross KW, Jones SC, Sheppard MC. Prevalence and follow-up of abnormal thyrotrophin (TSH) concentrations in the elderly in the United Kingdom. Clin Endocrinol (Oxt). 1991;34:77-83. [PMID: 2004476]

4. Sawin CT, Castelli WP, Hershman JM, McNamara P, Bacharach P. The aging thyroid. Thyroid deficiency in the Framinghan Study. Arch Intern Med. 1985;145:1386-8. [PMID: 4026469]

5. Surks MI, Ortiz E, Daniels GH, Sawin CT, Col NF, Cobin RH, et al. Subclinical thyroid disease: scientific review and guidelines for diagnosis and management. JAMA. 2004;291:228-38. [PMID: 14722150]

6. Cooper DS. Clinical practice. Subclinical hypothyroidism. N Engl J Med. 2001;345:260-5. [PMID: 11474665]

7. Ladenson PW, Singer PA, Ain KB, Bagchi N, Bigos ST, Levy EG, et al. American Thyroid Association guidelines for detection of thyroid dysfunction. Arch Intern Med. 2000;160:1573-5. [PMID: 10847249]

8. Villar $\mathrm{H}$, Saconato $\mathrm{H}$, Valente $\mathrm{O}$, Atallah $\mathrm{A}$. Thyroid hormone replacement for subclinical hypothyroidism. Cochrane Database Syst Rev. 2007(3): CD003419. [PMID: 17636722]

9. Althaus BU, Staub JJ, Ryff-De Lèche A, Oberhänsli A, Stähelin HB. LDL/ HDL-changes in subclinical hypothyroidism: possible risk factors for coronary heart disease. Clin Endocrinol (Oxf). 1988;28:157-63. [PMID: 3168304]

10. Canaris GJ, Manowitz NR, Mayor G, Ridgway EC. The Colorado thyroid disease prevalence study. Arch Intern Med. 2000;160:526-34. [PMID:

$$
3 \text { June } 2008 \mid \text { Annals of Internal Medicine } \mid \text { Volume } 148 \cdot \text { Number } 11 \mid 843
$$




\section{REVIEW $\mid$ Subclinical Thyroid Dysfunction and Coronary Heart Disease or Mortality}

\section{3]}

11. Kanaya AM, Harris F, Volpato S, Pérez-Stable EJ, Harris T, Bauer DC, Association between thyroid dysfunction and total cholesterol level in an older biracial population: the health, aging and body composition study. Arch Intern Med. 2002;162:773-9. [PMID: 11926850]

12. Hak AE, Pols HA, Visser TJ, Drexhage HA, Hofman A, Witteman JC. Subclinical hypothyroidism is an independent risk factor for atherosclerosis and myocardial infarction in elderly women: the Rotterdam Study. Ann Intern Med. 2000;132:270-8. [PMID: 10681281]

13. Monzani F, Caraccio N, Kozàkowà M, Dardano A, Vittone F, Virdis A, et al. Effect of levothyroxine replacement on lipid profile and intima-media thickness in subclinical hypothyroidism: a double-blind, placebo- controlled study. J Clin Endocrinol Metab. 2004;89:2099-106. [PMID: 15126526]

14. Cappola AR, Fried LP, Arnold AM, Danese MD, Kuller LH, Burke GL, et al. Thyroid status, cardiovascular risk, and mortality in older adults. JAMA. 2006;295:1033-41. [PMID: 16507804]

15. Parle JV, Maisonneuve P, Sheppard MC, Boyle P, Franklyn JA. Prediction of all-cause and cardiovascular mortality in elderly people from one low serum thyrotropin result: a 10-year cohort study. Lancet. 2001;358:861-5. [PMID: 11567699]

16. Rodondi N, Newman AB, Vittinghoff E, de Rekeneire N, Satterfield S, Harris TB, et al. Subclinical hypothyroidism and the risk of heart failure, other cardiovascular events, and death. Arch Intern Med. 2005;165:2460-6. [PMID: $16314541]$

17. Walsh JP, Bremner AP, Bulsara MK, O'Leary P, Leedman PJ, Feddema P, et al. Subclinical thyroid dysfunction as a risk factor for cardiovascular disease. Arch Intern Med. 2005;165:2467-72. [PMID: 16314542]

18. Rodondi N, Aujesky D, Vittinghoff E, Cornuz J, Bauer DC. Subclinical hypothyroidism and the risk of coronary heart disease: a meta-analysis. Am J Med. 2006;119:541-51. [PMID: 16828622]

19. Gussekloo J, van Exel E, de Craen AJ, Meinders AE, Frölich M, Westendorp RG. Thyroid status, disability and cognitive function, and survival in old age. JAMA. 2004;292:2591-9. [PMID: 15572717]

20. Imaizumi $M$, Akahoshi $M$, Ichimaru $S$, Nakashima $E$, Hida $A$, Soda $M$, et al. Risk for ischemic heart disease and all-cause mortality in subclinical hypothyroidism. J Clin Endocrinol Metab. 2004;89:3365-70. [PMID: 15240616] 21. Stroup DF, Berlin JA, Morton SC, Olkin I, Williamson GD, Rennie D, et al. Meta-analysis of observational studies in epidemiology: a proposal for teporting. Meta-analysis Of Observational Studies in Epidemiology (MOOSE) group. JAMA. 2000;283:2008-12. [PMID: 10789670]

22. Medline cohort study filter. Search filters; 2007 . Filter designed by knowledge information specialists from British Medical Joumnal. Accessed at www.dinical evidence.com/ceweb/about/search_filcers.jsp on13 February 2008.

23. Haugen B. When Isn't the TSH Normal and Why? Clinical Implications and Causes [Presented paper]. 12th Annual Meeting of the American Association of Clinical Endocrinologists, 14-18 May 2003, San Diego, California.

24. Lee S. When Is the TSH Normal? New Criteria for Diagnosis and Management [Presented paper]. 12th Annual Mecting of the American Association of Clinical Endocrinologists, 14-18 May 2003, San Diego, California.

25. Aho K, Gordin A, Palosuo T, Punsar S, Valkeila E, Karvonen M, et al. Thyroid autoimmunity and cardiovascular diseases. Eur Heart J. 1984;5:43-6. [PMID; 6705804]

26. Bauer DC, Rodondi N, Stone KL, Hillier TA. Study of Osteoporotic Fractures Research Group: Universities of California (San Francisco), Pittsburgh, Minnesota (Minneapolis); Kaiser Permanente Center for Health Research, Portland. Thyroid hormone use, hyperthyroidism and mortality in older women. Am J Med, 2007;120:343-9. [PMID: 17398229]

27. Smith SC Jr, Dove JT, Jacobs AK, Kennedy JW, Kereiakes D, Kern MJ, et al. American College of Cardiology; American Heart Association Task Force on Practice Guidelines. Committee to Revise the 1993 Guidelines for Percutaneous Transluminal Coronary Angioplasty. ACC/AHA guidelines of percutaneous coronary interventions (revision of the 1993 PTCA guidelines) - executive summary. A report of the American College of Cardiology/American Heart Association Task Force on Practice Guidelines (committee to revise the 1993 guidelines for percutaneous transluminal coronary angioplasty). J Am Coll Cardiol. 2001;37:2215-39. [PMID: 11419905]

28. Egger M, Davey Smith G, Altman DG. Systematic Reviews in Health Care: Meta-analysis in Context. 2nd ed. London: BMJ; 2001.

29. Hulley SB, Cummings SR, Browner WS, Grady D, Hearst N, Newman TB. Designing Clinical Research: An Epidemiologic Approach. Philadelphia:
Lippincott Williams \& Wilkins; 2001.

30. Vanderpump MP, Tunbridge WM, French JM, Appleton D, Bates D, Clatk F, et al. The development of ischemic heart disease in relation to autoimmune thyroid disease in a 20-year follow-up study of an English community. Thyroid. 1996;6:155-60. [PMID: 8837320]

31. Iervasi G, Molinaro S, Landi P, Taddei MC, Galli E, Mariani F, et al. Association between increased mortality and mild thyroid dysfunction in cardiac patients. Arch Intern Med. 2007;167:1526-32. [PMID: 17646607]

32. Radácsi A, Kovács G, Bernard W, Feldkamp J, Horster FA, Szabolcs I. Mortality rate of chronically ill geriatric patients with subnormal serum thyrotropin concentration: a 2-yr follow-up study. Endocrine. 2003;21:133-6. [PMID: 12897375]

33. Ernst E, Resch KL. Fibrinogen as a cardiovascular risk factor: a meta-analysis and review of the literature. Ann Intern Med. 1993;118:956-63. [PMID: 8489110]

34. Gorham ED, Garland CF, Garland FC, Grant WB, Mohr SB, Lipkin M, et al. Optimal vitamin $\mathrm{D}$ status for colorectal cancer prevention: a quantitative meta analysis, Am J Prev Med. 2007;32:210-6. [PMID: 17296473]

35. Woolf $\mathrm{B}$. On estimating the relation between blood group and disease. Ann Hum Genet. 1955;19:251-3. [PMID: 14388528]

36. DerSimonian R, Laird N. Meta-analysis in clinical trials, Control Clin Trials. 1986;7:177-88. [PMID: 3802833]

37. Petitti DB. Approaches to heterogeneity in meta-analysis. Stat Med. 2001; 20:3625-33. [PMID: 11746342]

38. Higgins JP, Thompson SG, Deeks JJ, Altman DG. Measuring inconsistency in meta-analyses. BM]. 2003;327:557-60. [PMID: 12958120]

39. Cooper DS. Thyroid disease in the oldest old: the exception to the rule [Editorial]. JAMA. 2004;292:2651-4. [PMID: 15572724]

40. Sazawal S, Black RE.Pneumonia Case Management Trials Group. Effect of pneumonia case management on mortality in neonates, infants, and preschool children: a meta-analysis of community-based trials. Lancet Infect Dis. 2003;3: 547-56. [PMID: 12954560]

41. Tobias A. Assessing the influence of a single study in meta-analysis. Stata Tech Bull. 1999;47:15-17.

42. Egger M, Davey Smith G, Schneider M, Minder C. Bias in meta-analysis detected by a simple, graphical test. BMJ, 1997;315:629-34. [PMID: 9310563] 43. Goldman MB, Monson RR, Maloof F. Cancer mortality in women with thyroid disease. Cancer Res. 1990;50:2283-9. [PMID: 2317816]

44, van den Beld AW, Visser TJ, Feelders RA, Grobbee DE, Lamberts SW. Thyroid hormone concentrations, disease, physical function, and mortality in elderly men. J Clin Endocrinol Metab. 2005;90:6403-9. [PMID: 16174720] 45. Bossoni S, Cossi S, Marengoni A, De Martinis M, Calabrese P, Leonardi R, et al. The negative role of subclinical thyrotoxicosis on the outcome of hospitalized geriatric patients. J Endocrinol Invest. 2002;25:64-5. [PMID: 12508921] 46. Davis PJ, Davis FB. Hyperthyroidism in patients over the age of 60 years. Clinical features in 85 patients. Medicine (Baltimore). 1974;53:161-81. [PMID: 4133091]

47. Friberg L, Drvota V, Bjelak AH, Eggertsen G, Ahnve S. Association between increased levels of reverse triiodothyronine and mortality after acute myocardial infarction. Am J Med. 2001;111:699-703. [PMID: 11747849]

48. Kaptein EM, Weiner JM, Robinson WJ, Wheeler WS, Nicoloff JT. Relationship of altered thyroid hormone indices to survival in nonthyroidal illnesses. Clin Endocrinol (Oxf). 1982;16:565-74. [PMID: 7105428]

49. Nyirenda MJ, Clark DN, Finlayson AR, Read J, Elders A, Bain M, et al. Thyroid disease and increased cardiovascular risk. Thyroid. 2005;15:718-24. [PMID: 16053389]

50. Peters A, Ehlers M, Blank B, Exler D, Falk C, Kohlmann T, et al. Excess triiodothyronine as a risk factor of coronary events. Arch Intern Med. 2000;160: 1993-9. [PMID: 10888973]

51. Alevizaki M, Synetou M, Xynos K, Pappa T, Vemmos KN. Low triiodothyronine: a strong predictor of outcome in acute stroke patients. Eur J Clin Invest. 2007;37:651-7. [PMID: 17635576]

52. Enia G, Panuccio V, Cutrupi S, Pizzini P, Tripepi G, Mallamaci F, et al. Subclinical hypothyroidism is linked to micro-inflammation and predicts death in continuous ambulatory peritoneal dialysis. Nephrol Dial Transplant. 2007;22: 538-44. [PMID: 17082213]

53. Carrero JJ, Qureshi AR, Axelsson J, Yilmaz MI, Rehnmark S, Witt MR, et al. Clinical and biochemical implications of low thyroid hormone levels (total and free forms) in euthyroid patients with chronic kidney disease. J Intern Med. 2007;262:690-701. [PMID: 17908160] 
54. Bastenie PA. Hypothyroidism and coronary heart disease. Acta Cardiol. 1982;37:365-73. [PMID: 6983807]

55. Kent S. Hormones and heart disease. Geriatrics. 1979;34:97-102. [PMID: 447079]

56. Popovici D. The thyroid and the cardio-vascular system. Major physiopathologic aspects with clinical and therapeutic implications. Endocrinologie. 1980;18: 293-4. [PMID: 7209361]

57. Osman F, Franklyn JA, Holder RL, Sheppard MC, Gammage MD. Cardiovascular manifestations of hyperthyroidism before and after antithyroid therapy: a matched case-control study. J Am Coll Cardiol, 2007;49:71-81. [PMID: 17207725]

58. Waterhouse DF, McLaughlin AM, Walsh CD, Sheehan F, O'Shea D. An examination of the relationship between normal range thyrotropin and cardiovascular risk parameters: a study in healthy women. Thyroid. 2007;17:243-8. [PMID: 17381358]

59. Bell RJ, Rivera-Woll L, Davison SL, Topliss DJ, Donath S, Davis SR. Well-being, health-related quality of life and cardiovascular disease risk profile in women with subclinical thyroid disease - a community-based study. Clin Endocrinol (Oxf). 2007;66:548-56. [PMID: 17371474]

60. Kaji H, Iida K, Takahashi Y, Okimura Y, Chihara K. Hormone replacement therapy and vascular risk disorders in adult hypopituitarism. Endocr J. 2007;54:239-45. [PMID: 17283380]

61. Flynn RW, Macdonald TM, Jung R'T, Morris AD, Leese GP. Mortality and vascular outcomes in patients treated for thyroid dysfunction. J Clin Endocrinol Metab. 2006;91:2159-64. [PMID: 16537678]

62. Singer RB. Mortality in a complete 4-year follow up of 85-year-old residents of Leiden, classified by serum level of thyrotropin and thyroxine. J Insur Med. 2006;38:14-9. [PMID: 16642639]

63. Demers LM, Spencer CA. Laboratory Support for the Diagnosis and Monitoring of Thyroid Disease. Laboratory Medicine Practice Guidelines. Washington, DC: National Academy of Clinical Biochemistry; 2002. Accessed at
www.aacc.org/NR/rdonlyres/407336C7-28E5-4728-BBD4-0E0FD41793CB/0 /ThyroidFullVersionwithCover.pdf on 13 February 2008.

64. Singh S, Duggal J, Molnar J, Maldonado F, Barsano CP, Arora R. Impact of subclinical thyroid disorders on coronary heart disease, cardiovascular and all-cause mortality: a meta-analysis. Int J Cardiol. 2008;125:41-8. [PMID: 17434631]

65. Rodondi N, Newman AB, Cappola AR, Bauer DC. Association between subclinical hypothyroidism and coronary heart disease in 2006. Int J Cardiol. 2007. [PMID: 18031844]

66. Völzke H, Schwahn C, Wallaschofski H, Dörr M. Review: The association of thyroid dysfunction with all-cause and circulatory mortality: is there a causal relationship? J Clin Endocrinol Metab. 2007:92:2421-9. [PMID: 17473067] 67. Kvetny J, Heldgaard PE, Bladbjerg EM, Gram J. Subclinical hypothyroidism is associated with a low-grade inflammation, increased triglyceride levels and predicts cardiovascular disease in males below 50 years. Clin Endocrinol (Oxf). 2004:61:232-8. [PMID: 15272919]

68. Psaty BM, Anderson M, Kronmal RA, Tracy RP, Orchard T, Fried LP, et al. The association between lipid levels and the risks of incident myocardial infarction, stroke, and total mortality: The Cardiovascular Health Study. J Am Geriatr Soc. 2004;52:1639-47. [PMID: 15450039]

69. Altman DG. Systematic reviews of evaluations of prognostic variables. BMJ. 2001;323:224-8. [PMID: 11473921]

70. Berlin JA. Invited commentary; benefits of heterogeneity in meta-analysis of data from epidemiologic studies. Am J Epidemiol. 1995;142:383-7. [PMID: 7625402]

71. Ross DS. Serum thyroid-stimulating hormone measurement for assessment of thyroid function and disease. Endocrinol Metab Clin North Am. 2001;30: 245-64, vii. [PMID: 11444162]

72. Begg CB, Mazumdar M. Operating characteristics of a rank correlation test for publication bias. Biometrics. 1994;50:1088-101. [PMID: 7786990]

73. Hunt JR, White E. Retaining and tracking cohort study members. Epidemiol Rev. 1998;20:57-70. [PMID: 9762509]

\section{ANNALS AUDIO SUMMARIES}

Author interviews and audio summaries of each Annals issue are now available at www.annals.org. For transcripts, or for instructions on how to download to a portable MP3 player, go to www.annals.org/podcast. You may also subscribe directly through iTunes.

After listening, send feedback to podcast@acponline.org. 
Current Author Addresses: Drs. Ochs, Nanchen, Cornuz, and Rodondi: Department of Ambulatory Care and Community Medicine, University of Lausanne, Bugnon 44, 1011 Lausanne, Switzerland.

Dr. Auer: Department of Medicine, University of Lausanne, Bugnon 46, 1011 Lausanne, Switzerland.

Dr. Bauer: University of California, San Francisco, 185 Berry Street, Suite 5700, San Francisco, CA 94107.

Dr. Gussekloo: Department of Public Health and Primary Care, Leiden University Medical Center, V06-P, Postbus 9600, 2300 RC Leiden, the Netherlands.

\section{Appendix Table 2. Stratified Analysis of the Association of Subclinical Hypothyroidism with Risk for Total Mortality*}

\section{Characteristic}

Eligible study model

Random effects

Fixed effects

Study quality

$<5 \%$ of participants lost to follow-up

Stratified by mean age§

$<65$ y

$\geq 65 y$

$<60 y$

$60-79.9$ y

$\geq 80 y$

\section{Adjustments}

Adjusted analyses or matching

Adjusted for cardiovascular risk factors

Definition of subclinical hypothyroidism

$\mathrm{TSH}$ level $\geq 4.5 \mathrm{mU} / \mathrm{L}$

$\mathrm{TSH}$ level $\geq 10.0 \mathrm{mU} / \mathrm{L}$

Particular population; elderly participants excluded (19)

Subsidiary analysis: addition of a convenience sample of cardiac patients (31)
Summary Relative Risk

$(95 \% \mathrm{Cl})+$

Studies,

$n$

$1.12(0.99-1.26)$

$1.12(0.99-1.26)$

6

6

$1.13(0.99-1.28)$

4

$1.20(0.80-1.60)$

$1.10(0.96-1.26)$

$1.20(0.80-1.60)$

$1.12(0.99-1.28)$

$0.55(0.24-1.25)$

$1.12(0.99-1.26$

$1.15(1.00-1.32)$

6.

$1.12(0.99-1.26)$

$2.05(0.90-4.68)$

$1,13(1,00-1,28)$

5

$1.18(0.96-1.44) \|$

7

* TSH $=$ thyroid-stimulating hormone.

+ Relative risk from meta-analysis using random-effects model.

$\mp$ A cutoff of $<5 \%$ of participants lost to follow-up was considered appropriate on the basis of retention data of other large cohort studies ( 73 ),

$\$$ The number of studies in each age category is small, with only 1 study in the younger age groups.

$\|$ Addition of the convenience sample of cardiac patients increased overall statistical heterogeneity $\left(P\right.$ for heterogeneity $\left.=0.08 ; I^{2}=47.6 \%\right)$.

ww.annals.org

3 June $2008 \mid$ Annals of Internal Medicine $\mid$ Volume $148 \cdot$ Number $11 \mid W_{\mathbf{n}} \mathbf{1 8 3}$ 


\section{Appendix Table 3. Stratified Analysis of the Association of Subclinical Hypothyroidism with Risk for Cardiovascular Mortality"}

Characteristic

Random effects

Fixed effects

Study quality

Formal cardiovascular mortality rate adjudication procedures

Adjudication without knowledge of thyroid status

Stratified by mean age

$<65 y$

$\geq 65 y$

$<60 y$

$60-79.9$ y

$\geq 80 y$

\section{Adjustments}

Adjusted analyses or matching

Adjusted for cardiovascular risk factors

$1.18(0.98-1.42)$

$1.17(0.92-1.49)$

$1.13(0.92-1.39)$

$2.26(0.54-9.45)$

$1.20(0.99-1.44)$

$1.29(1.01-1.67) \neq$

Studies,

\section{8}

4

6

Definition of subclinical hypothyroidism

TSH level $\geq 4.5 \mathrm{mU} / \mathrm{L}$

Particular population: elderly participants excluded (19)

Subsidiary analysis: addition of a convenience sample of cardiac patients (31)

* $\mathrm{TSH}=$ thyroid-stimulating hormone.

† Relative risk from meta-analysis by using random-effects model.

\# Addition of the convenience sample of cardiac patients increased overall statistical heterogeneity $\left(P\right.$ for heterogeneity $\left.=0.24 ; I^{2}=23.4 \%\right)$.

Appendix. Trble 4. Stratified Analysis of the Assoclation of Subclinical Hyperthyroidism with Risk for Total Mortality*

\section{Characteristics}

Eligible study model

Random effects:

Fixed effects
Summary Relative Risk

$(95 \% \mathrm{Cl}) \dagger$

$1.12(0.89-1.42)$

$1.12(0.89-1.42)$

$1.12(0.87-1.43)$

$<5 \%$ of participants lost to follow-up $\neq$

Adjustments

Adjusted analyses or matching

Adjusted for cardiovascular risk factors

Particular population: elderly participants excluded (19)

Subsidiary analysis: addition of 2 convenience samples (31, 32)
$1.12(0.89-1.42)$

$1.08(0,72-1,62)$

$1.12(0.87-1.43)$

$1.19(0.97-1.47) \xi$
Studies,

* Stratified analyses by mean age are not reported for this relationship because of the limited number of studies.

+ Relative risk from meta-analysis using random-effects model.

$\ddagger$ A cutoff of $<5 \%$ of participants lost to follow-up was considered appropriate on the basis of retention data of other large cohort studies ( 73 ).

$\S$ Addition of the 2 convenience samples did not increase overall statistical heterogeneity ( $P$ for heterogeneity $=0.82 ; I^{2}=0 \%$ ). 
Appendix Table 5. Stratified Analysis of the Association of Subclinical Hyperthyroidism with Risk for Cardiovascular Mortality*

Characteristics

Eligible study model

Random effects

Fixed effects

tudy quality

Formal cardiovascular mortality rate adjudication procedures

Adjudication without knowledge of thyroid status

\section{Adjustments}

Adjusted analyses or matching

Adjusted for cardiovascular risk factors

Particular population: elderly participants excluded (19)

Subsidiary analysis: addition of 2 convenience samples $(31,32)$
Summary Relative Risk

$(95 \% \mathrm{Cl})+$

Studies,

5

$1.19(0.81-176)$

$1.19(0.81-1.76)$

$1.01(0.60-1.69)$

$1.21(0.81-1.81)$

3

$1.19(0.81-176)$

$0.95(0.52-1.74)$

$1.17(0.77-177)$

$1.55(0.99-2.43)+$

* Stratified analyses by mean age are not reported for this relationship because of the limited number of studies.

+ Relative risk from meta-analysis using random-effects model.

$¥$ Addition of the 2 convenience samples increased overall statistical heterogeneity ( $P$ for heterogeneity $=0.17 ; I^{2}=34.0 \%$ ). 


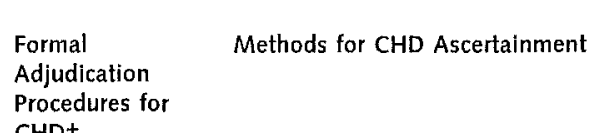

Adjudication
Procedures for
CHD†

Population-based studies
Aho et al., 1984 (25)

Vanderpump et al, 1996 (30) (Which

study)
Hak et

Parle et al., 2001 (15)

Imaizumi et ali, 2004 (20) (Nagasaki Adult

Gussekloo et al., 2004 (19) (Leiden 85-plus

Study)
Rododdi et al, 2005 (16) (Health, Aging, and
Body Compostiton Study)

\section{Walsh et al., 2005 (17) (Busselton Health
Study)}

Cappola et al., 2006 (14) (Cardiovascular
Health Study)

Bauer et al., 2007 (26) (Study of Osteoporotic
Fractures)

Convenience samples
Radácsi et alli, $2003(32)$

lervasi et al., 2007 (31)
NA

Yes

NA NA practititioners or hospital records
Repoorts from general practititioners and hospital records NA

Interview, hospital records, and other support documents revriew, hospital records, and other support documents
reviewed by a panel of clinicians

Hospital records: diagnoses coded with ICD-9 and ICD-10 No

Interview, hospital records reviewed by experts

NA

NA

NA

Yes

Yes
Methods for Cardiovascular Mortality Rate Ascertainment

Formal
Adjudication

Adjudication
Procedures
foflos

Cardiovascular

Mortality
Ratet

No

No Death information obtained from general practitioners
NR
Death certificates, postmortem reports, hospital or general practitioners' reports,
WCCC dufing

Death certificates; causes of death coded with ICD-9

Mortality information from general practitioners with a standardized

Hospital records, death certificitetes, and other support documents reviewed by a
panel of clinicians

Registrar General's list of deaths: coded with ICD-9 and ICD-10

Medical records, death certificates, autopsy reports, and coroners' reports reviewed by expert

Hospital records, death certfificates reviewed by a physician-investigator and
coded with ICD-9 (if living

\begin{tabular}{ll|}
$\begin{array}{l}\text { Adjudcation } \\
\text { without } \\
\text { Knowledge } \\
\text { of Thyroid } \\
\text { Status }\end{array}$ & $\begin{array}{l}\text { Lost to } \\
\text { Follow-up, \% }\end{array}$ \\
& \\
No & NR \\
Yes & 3 \\
Yes & 1.8 \\
Yes & 0.1 \\
Yes & 0 for mortality \\
Yes & 12.5 \\
Yes & NR \\
& \\
&
\end{tabular}

Yes

Yes

No
Adjustments

ge- and locality-matched, unadjusted
Unadiusted

Age, BMI, total cholesterol, HDL, BP and smoking
Age and sex

Age and sex
Age, sex, and smoking

Sex and education

Age, sex, race, smoking, diabetes,
reveralent

$B P$, total cholesterol, creatinine,

ducation, income, thyroid

Age, sex, BMI, smoking, diabetes, total cholesterol, triglycerides, $\mathrm{BP}$, thyroid disease Age, sex, prevalent CVD, thyroid nealcation, race, smoking, diabetes, drugs, hypertension, BMt, and CR Ge, weight, thyroid hormone or estrogen use, history of

$\begin{array}{ll}\text { Unadjusted } & \text { NR } \\ \text { Age, sex, ischemic and nonischemic } & \text { NR }\end{array}$

"If an article did not clearly mention 1 of these characteristics, we considered it not to have been done. ACE $=$ angiotensin-converting enz

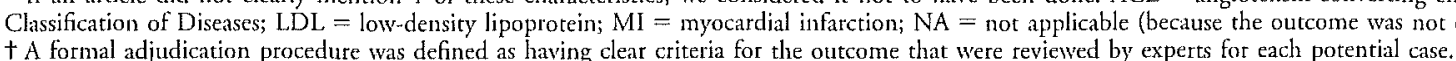

